\title{
EosInophil cationic protein as a serological marker of disease activity in childhood bronchial asthma
}

\author{
O.M. Badr-El-Din, ' I.H. El-Sawy, ${ }^{1}$ O.E. El-Azzouni, ' M.M.A. Badr-El-Din'
} and A.M. Salem'

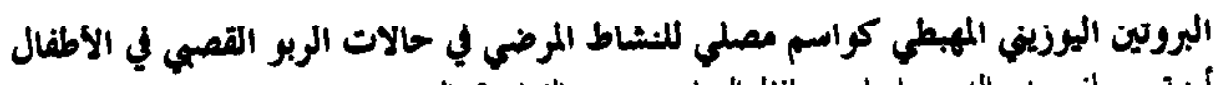

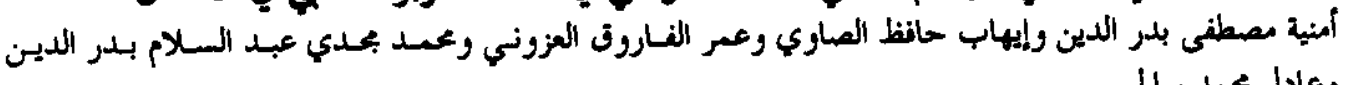
وعادل معد بعالم

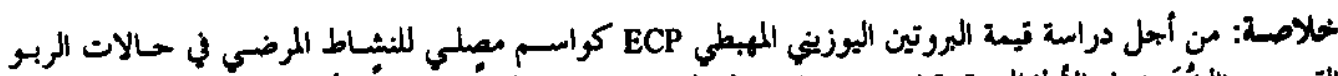

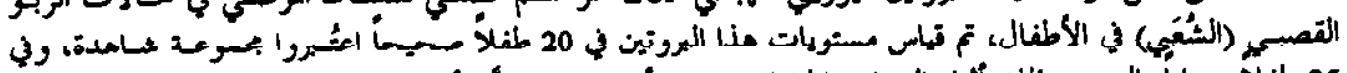

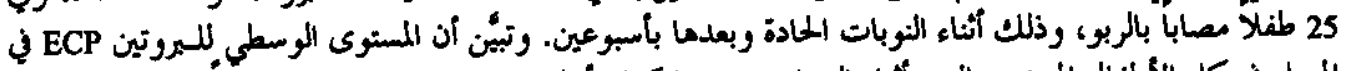

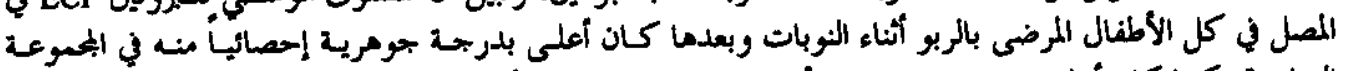

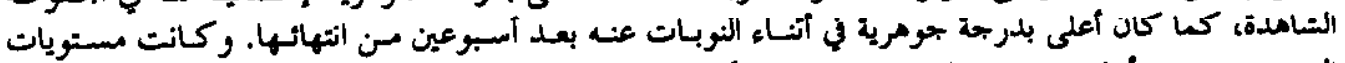

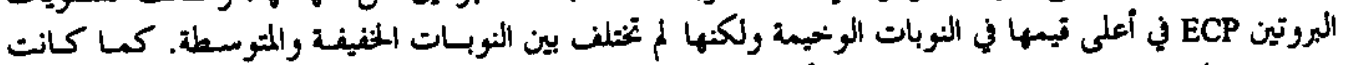

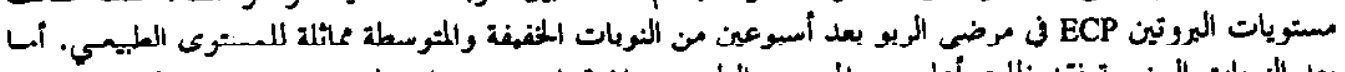

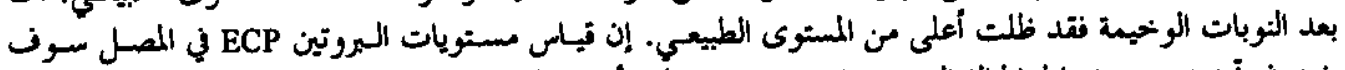

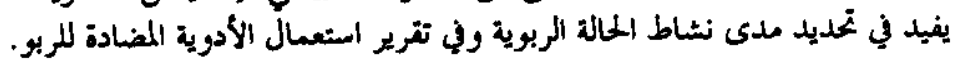

ABSTRACT To study the value of eosinophil cationic protein (ECP) as a serological marker of disease activity in childhood bronchial asthma, ECP levels were measured in 20 healthy control children and 25 aethmatic childron, during and 2 weeks after acute exacebation. The mean serum ECP level of all asthmatic patients, during and after exacerbation, was significantly higher than the control group and was significantly higher during attacks than 2 weoks after their termination. ECP levels were highest in severe attacks, but did not differ between mild and moderate attacks. ECP levels in asthmatic patients 2 weeks after mild and moderate attacks wore oomparablo to normal; after sovero attacks levals remained hioher than normal. Measurement of serum ECP will be helpful in determining asthma activity and deciding the use of anti-asthma drugs.

La protéine cationique dérivée des tosinophlles en tant que marqueur órologique d'6volutivité de l'asthme bronchique chez l'enfant

RESUME Pour étudier la valeur de la protéine cationique dérivée des éosinophiles (ECP) en tant que marqueur sérologique d'évolutivité de la maladie dans l'asthme bronchique chez l'enfant, les taux d'ECP ont été mesurés chez 20 enfants témoins en bonne santé et 25 enfants asthmatiques pendant l'exacerbation aigué et deux semaines après. Le taux sérique moyen d'ECP chez tous les asthmatiques, pendant et après l'exacerbation, était considérablement plus élevé que celui du groupe témoin et il était considérablement plus élevé pendant les crisos que deux semaines après la fin de celles-ci. Les taux d'ECP étaient les plus élevés durant les crises sévères mais if n'y avait pas de différence entre les crises légères et modérées. Les taux d'ECP chez les asthmatiques deux semaines après des crises légères et modérées étaient comparables à la normale; après des crises sévères, les taux demeuraient supérieurs à la normale. La mesure de l'ECP sérlque sera utlle pour déterminer l'évolutivité de l'asthme et décider de l'utilisation d'antiacthmatiques.

'Department of Paediatrics, Faculty of Medicine, Alexandria University, Alexandria, Egypt.

Received: 08/04/99; accepted: 01/07/99

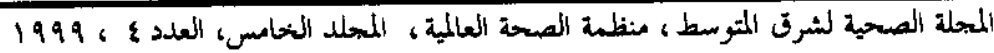




\section{Introduction}

Bronchial asthma is a chronic inflammatory disease of the alrway, and the cells mainly responsible for causing this inflammation are eosinophils [ 1$]$. When activated eosinophils undergo degranulation causing epithelial damage in the airway, desquamation and increased airway hypersensitivity [2]. Asthma therapy consists of suppressing chronic and persistent airway inflammation [3]. It is, therefore, important to find a marker of disease activity, ideally one that is simple to measure, reliable and inexpensive. As yet no such marker has been found for asthma.

Eosinophil cationic protein (ECP) is an eosinophil granule protein which is highly cytotoxic and is released by activated eosinophils [4]. Concentrations of ECP in the bronchoalveolar lavage fluid (BALF) of asthma patients vary with the severity of their disease and ECP concentrations in sputum have also been shown to reflect the pathophysiology of the disease $[5,6]$. The concentration of serum ECP has recently been found to correlate with ECP concentration in the bronchial wash and BALF [7]. Therefore, assessment of serum ECP may be assumed to reflect pulmonary inflammation in bronchial asthma [8]. Studies of asthmatic patients, especially adults, have indicated a relationship between the level of serum ECP and the severity and nature of the disease [7-9]. Therefore, in this study we assessed the value of measuring serum ECP as a serological marker of airway inflammatory activity in childhood asthma.

\section{Subjects and methods}

Initially we assessed 38 asthmatic children with acute exacerbation, but were only able to conduct a complete study of 25 cases.
Thirteen cases were omitted; three were admitted to the intensive care unit, four were discharged at their own request before complete recovery and six went missing during the follow-up period. Cases were recruited from the outpatient and emergency departments of El-Chatby University Children's Hospital between January and July 1998. The diagnosis of asthma was based on a history of recurrent episodes of wheezing and on a physical examination. Patients who had received drugs which might affect their ECP level, e.g. systemic or inhaled corticosteroids, cromolyn sodium or any oral antiallergic drugs during the 2 weeks prior to enrolment into the study were excluded $[10,11]$. Asthmatic patients with other allergic or inflammatory disorders were also excluded from the study.

Twenty apparently healthy children of matching age and sex were studied as a control group. None of the control group had a past history of asthma or other allergic conditions. The study was approved by the Research Committee of the Alexandria Faculty of Medicine and informed consent to participate in the study was obtained from the parents or guardian of each child.

\section{Clinical and laboratory assessment} A detailed medical history was recorded and complete clinical examination conducted for all the patients. Before any therapeutic intervention was given, the asthmatic patients were classified as having mild (eight cases), moderate (eight cases) or severe (nine cases) attacks of asthma according to an asthma score [12]. The asthma score used included both clinical parameters (respiratory rate, alertness, dypsnoea, accessory muscle use, skin colnur, auscultatory findings) and physiological parameters (peak expiratory flow rate, oxygen saturation, $\mathrm{P}_{\mathrm{CO}_{2}}$ ) [12]. Plain $\mathrm{X}$-rays of the chest 
and heart were only taken for the asthmatic patients to exclude other causes of wheezy chest. Measurements of oxygen saturation $\left(\mathrm{O}_{2} \%\right)$ using a pulse oximeter and peak $\mathrm{cx}-$ piratory flow rate (PEFR) using a Wright flowmeter were taken for all the study population. Values of PEFR were expressed as a percentage of the predicted normal rate (by sex and height) using a previously calculated Egyptian standard. Measurement of the eosinophilic count used the counting chamber method.

\section{Measurement of serum ECP}

Serum ECP was determined using the double antibody radioimmunoassay (Pharmacia and Upjohn Diagnostics, USA). The ECP in the samples competes with a fixed amount of ${ }^{125} \mathrm{I}$-labelled ECP for the binding sites of specific antibodies. The intra-assay and inter-assay coefficients of variation were less than $11 \%$ and the detection limit was less than $2 \mu \mathrm{g} / \mathrm{L}$ [13]. Blood samples were carefully taken before any therapeutic intervention, using the standardized method recommended by the ECP supplier as the method of blood collection can substantially change the level of serum ECP. It can be spuriously increased by high ambient temperatures, if excessive time is allowed for clotting or by insufficient centrifugation and diurnal variation [4].

\section{Management and follow-up}

All the asthmatic children were managed according to the asthma protocol used at the hospital, i.e. nebulized salbutamol for mild cases and nebulized salbutamol plus systemic corticosteroids for moderate and severe cases. Patients were discharged from hospital when they fulfilled the following improvement criteria: no respiratory distress, no tachypnoea, oxygen saturation greater than $95 \%$ and PEFR greater than $80 \%$ of expected.
Wc hypothesized that for a test to be clinically useful it must distinguish between symptomatic and asymptomatic asthma and must normalize as the patient's condition comes under control. Accordingly, we repeated the investigations again 2 weeks after the patient's acute attack had ended. All patients were clinically free, their oxygen saturation and PEFR as a percentage of predicted were comparable to normal. No patients, either before or after enrolment in the study, were receiving maintenance therapy.

\section{Statistical analysis}

Statistical significance was analysed by the Student $t$-test (paired and unpaired), $F$-test (ANOVA), least significant difference, chisquared $\left(\chi^{2}\right)$ test and correlation coefficient $(r)$. $P$-values less than 0.05 were considered significant.

\section{Results}

No statistically significant differences were found between the asthmatic patients and the control group with regard to age, sex and height (Table 1).

The mean eosinophilic counts were significantly higher for asthmatic paticnts, both during and after their attacks, compared with the control children. However, no significant difference was found between the mean eosinophilic counts for asthmatic patients during their asthma attacks and 2 weeks anter the attacks (Table 2).

The mean serum ECP level was significantly higher in asthmatic patients, both during and after their attacks, compared with the control children. Moreover, the mean ECP level in asthmatic patients was significantly higher during their asthma attacks than after (Table 2). 
Table 1 Cherecterlstics of asthmatic patients and control group

\begin{tabular}{lccc}
\hline Characteristic & $\begin{array}{c}\text { Asthmatic patients } \\
(n=25)\end{array}$ & $\begin{array}{c}\text { Control group } \\
(n=20)\end{array}$ & Test of significance \\
\hline $\begin{array}{l}\text { Age (years) } \\
\text { Range }\end{array}$ & $5-14$ & $5-13$ & \\
Mean $\pm s$ & $8 \pm 2.36$ & $8.17 \pm 2.06$ & $t=0.26, P=0.795$ NS \\
Sex & & & \\
$\quad$ Male & $18(72 \%)$ & $11(55 \%)$ & \\
Female & $7(28 \%)$ & $9(45 \%)$ & $\chi^{2}=1.40, P=0.236 \mathrm{NS}$ \\
Height (cm) & & & \\
Range & $96-165$ & $111-155$ & \\
Mean $\pm s$ & $127.28 \pm 16.23$ & $129 \pm 12.70$ & $t=0.39, P=0.39 \mathrm{NS}$ \\
\hline
\end{tabular}

NS $=$ not significant $\quad S=$ standard deviation

Table 2 Eosinophilic counts and serum levels of eosinophil catlonic proteln (ECP) in the control group and all asthmatic patients, during and after the attacks

\begin{tabular}{|c|c|c|c|c|}
\hline Variable & $\begin{array}{l}\text { Control } \\
\text { group } \\
(n=20)\end{array}$ & $\begin{array}{c}\text { Asthma patients } \\
\text { (during attacks) } \\
(n=25)\end{array}$ & $\begin{array}{l}\text { Asthma patients } \\
\text { (after attacks) } \\
(n=\mathbf{2 5})\end{array}$ & $\begin{array}{c}\text { Test of } \\
\text { signiflcance }\end{array}$ \\
\hline \multicolumn{5}{|c|}{ Eosinophilic count (cells/cm) } \\
\hline $\begin{array}{l}\text { Range } \\
\text { Mean } \pm s\end{array}$ & $\begin{array}{c}50-600 \\
241 \pm 182.66\end{array}$ & $\begin{array}{c}100-2140 \\
635.8 \pm 566.05\end{array}$ & $\begin{array}{c}50-2250 \\
574 \pm 543.92\end{array}$ & $\begin{array}{l}t_{1}=2.99, P=0.005^{\mathrm{a}} \\
t_{2}=2.62, P=0.012^{\mathrm{b}} \\
t_{3}=0.53, P=0.59 \mathrm{NS}\end{array}$ \\
\hline $\begin{array}{l}E C P(\mu g /) \\
\text { Range } \\
\text { Mean } \pm s\end{array}$ & $\begin{array}{c}2-4.6 \\
2.8 \pm 0.77\end{array}$ & $\begin{array}{c}2.8-31 \\
12.67 \pm 8.87\end{array}$ & $\begin{array}{c}4-11 \\
5.53 \pm 2.45\end{array}$ & $\begin{array}{l}t_{1}=4.95, P=0.000^{\mathrm{a}} \\
t_{2}=4.79, P=0.000^{\mathrm{a}} \\
t_{3}=4.55, P=0.000^{\mathrm{a}}\end{array}$ \\
\hline
\end{tabular}

ap $<0.01 \quad$ bP $<0.05$

$\mathrm{t}_{1}=\mathrm{t}$-test between asthmatic patients during attacks and control group

$t_{2}=t$-test between asthmatic patients 2 weeks after the attacks and control group

$t_{3}$ - pairod t-test between asthmatic patients during and $z$ weoks after the attacks

NS = not significant $\quad \mathbf{s}=$ standard deviation

\section{Asthmatic subgroups during asthma attacks compared with the control group}

Measurement of the mean $\mathrm{O}$, saturation and PEFR (as a percentage of predicted) showed statistically significant differences between the asthmatic subgroups themselves and between the subgroups and the control children. The lowest levels were in the asthmatic subgroup suffering severe exacerbation and were highest in the control group (Table 3 ).

The mean eosinophilic count was significantly higher only in patients having severe attacks of bronchial asthma as compared with the control group. No statistically significant differences were found between the eosinophilic counts of patients 
Table 3 Physiological parameters, eosinophilic counts and eosinophil cationic protein (ECP) levele in the oontrol group and aothmatic subgroups during attecks

\begin{tabular}{|c|c|c|c|c|c|}
\hline Varlable & $\begin{array}{c}\text { Control } \\
(n=20)\end{array}$ & $\underset{(n=8)}{\text { Mild }}$ & $\begin{array}{c}\text { Moderate } \\
\qquad(n=9)\end{array}$ & $\begin{array}{l}\text { Severe } \\
(n=8)\end{array}$ & $\begin{array}{c}\text { Test of } \\
\text { slgnificance }\end{array}$ \\
\hline \multicolumn{6}{|c|}{$\mathrm{O}_{2}$ saturation (\%) } \\
\hline Mean & 99.30 & 95.75 & 92.33 & 87.75 & $F=197.74$ \\
\hline$s$ & 0.73 & 0.806 & 1.800 & 1.581 & $P=0.000$ \\
\hline \multicolumn{6}{|c|}{ PEFR (as \% of predicted) } \\
\hline Mean & 96.20 & 80.30 & 60.67 & 44.13 & $F=220.76$ \\
\hline$s$ & 5.586 & 5.823 & 5.099 & 3.907 & $P=0.000$ \\
\hline \multicolumn{6}{|c|}{ Eosinophilic count (cells/cm) } \\
\hline Mean & 241.00 & 487.5 & 493.88 & 943.75 & $F=5.399$ \\
\hline$s$ & 182.67 & 355.31 & 625.62 & 604.41 & $P=0.003$ \\
\hline \multicolumn{6}{|c|}{$E C P(\mu g / L)$} \\
\hline Mean & 2.80 & 9.77 & 10.03 & 18.57 & $F=13.683$ \\
\hline 5 & 0.77 & 7.24 & 6.14 & 10.66 & $P=0.000$ \\
\hline
\end{tabular}

PEFR = peak expiratory flow rate

$\mathbf{s}=$ standard deviation

Table 4 Least significant difference between asthmatic patient subgroups versus each other and versus the control group tor physlological parameters, eosinophillc counts and eosinophil cationic proteln (ECP) levels

\begin{tabular}{lcccc}
\hline Groups & $\mathrm{O}_{\mathbf{z}}$ safuration \% & PEFR & Eosinophilic count & ECP \\
\hline Control and mild & $1.46^{\mathrm{a}}$ & $15.10^{\mathrm{a}}$ & $511.00 \mathrm{NS}$ & $5.10^{\mathrm{a}}$ \\
Control and moderate & $1.60^{\mathrm{b}}$ & $15.10^{\mathrm{b}}$ & $593.41 \mathrm{NS}$ & $4.89^{\circ}$ \\
Control and severe & $1.46^{\mathrm{b}}$ & $15.10^{\mathrm{b}}$ & $511.00^{\mathrm{a}}$ & $5.10^{\mathrm{a}}$ \\
Mild and moderate & $1.70^{\mathrm{a}}$ & $19.44^{\mathrm{a}}$ & $593.41 \mathrm{NS}$ & $5.92 \mathrm{NS}$ \\
Mild and sovere & $1.76^{\mathrm{b}}$ & $10.44^{\mathrm{b}}$ & $610.76 \mathrm{NS}$ & $0.09^{\circ}$ \\
Moderate and severe & $1.70^{\mathrm{a}}$ & $19.44^{\mathrm{b}}$ & $593.41 \mathrm{NS}$ & $5.92^{\mathrm{a}}$ \\
\hline
\end{tabular}

$P$ P $<0.05 \quad$ DP $<0.01$

$P E F R=$ peak expiratory flow rate $\quad N S=$ not significant

with mild and moderate attacks when compared with the control group or compared with each other (Table 3).

The mean serum ECP level was significantly higher in asthmatic patients with mild, moderate and severe attacks compared with the control group. Furthermore, the level was significantly higher in asth- matic patients with severe asthma attacks compared with those with mild and moderate attacks. However, no significant difference was found between mean serum ECP levels in patients with mild attacks when compared with those with moderate attacks (Table 4). 
Table 5 Physiological parameters, eosinophllic counts and eosinophil cationic protein (ECP) levels in the control group and asthmatic subgroups after termination of the atteoks

\begin{tabular}{|c|c|c|c|c|c|}
\hline Variable & $\begin{array}{l}\text { Control } \\
(n=20)\end{array}$ & $\begin{array}{c}\text { Mild } \\
(n=8)\end{array}$ & $\begin{array}{c}\text { Moderate } \\
(n=9)\end{array}$ & $\begin{array}{l}\text { Sovere } \\
(n=8)\end{array}$ & $\begin{array}{c}\text { Test of } \\
\text { significance }\end{array}$ \\
\hline \multicolumn{6}{|c|}{$\mathrm{O}_{2}$ saturation (\%) } \\
\hline Mean & 99.30 & 98.75 & 99.22 & 98.25 & $F=2.84$ \\
\hline$s$ & 0.73 & 0.70 & 0.83 & 1.49 & $P=0.06 \mathrm{NS}$ \\
\hline \multicolumn{6}{|c|}{ PEFR (as \% of predicted) } \\
\hline Mean & 96.20 & 95.71 & 94.20 & 86.71 & $F=0.689$ \\
\hline$s$ & 5.588 & 6.91 & 10.91 & 5.66 & $P=0.563 \mathrm{NS}$ \\
\hline \multicolumn{6}{|c|}{ Eosinophilc count (cells/cm) } \\
\hline Mean & 241.00 & 393.75 & 566.66 & 762.5 & $F=3.65$ \\
\hline$s$ & 182.67 & 326.71 & 671.75 & 560.45 & $P=0.02$ \\
\hline \multicolumn{6}{|c|}{$E C P(\mu g / L)$} \\
\hline Mean & 2.80 & 4.53 & 4.55 & 7.65 & $F=17.95$ \\
\hline $\mathbf{s}$ & 0.77 & 1.17 & 1.79 & 2.88 & $P=0.001^{\circ}$ \\
\hline
\end{tabular}

$4 P<0.05 \quad$ DP $<0.01$

PEFR = peak expiratory flow rate $s=$ standard deviation $\quad N S=$ not significant

\section{Asthmatic subgroups after asthma attacks compared with the control group}

No statistically significant differences were found between patients after termination of their asthma attacks and the control group with regard to $\mathrm{O}_{2}$ saturation and PEFR (as a percentage of predicted) (Table 5). However, the mean eosinophilic count was significantly higher in asthmatic patients after termination of severe attacks as compared with the control group but not significantly different after termination of mild or moderate attacks (Table 5).

The serum ECP levels showed no statistically significant differences between the control group and asthmatic patients after termination of mild or moderate attacks, but there was a significant difference in levels after termination of severe attacks compared with patients after termination of mild and moderate attacks and the control group (Table 6).
Oxygen saturation and PEFR increased significantly for all asthmatic subgroups after termination of their attacks. For eosinophilic counts no statistically significant differences were found between asthmatic subgroups after termination of the attacks compared with during the attacks. The ECP levels decreased significantly in all asthmatic subgroups after termination of the attacks when compared with the levels during the attacks (Table 7).

\section{Correlatlon between serum ECP levels and other parameters}

No statistically significant correlations could be found between serum FCP levels, oxygen saturation $(r=0.378, P=0.062)$, PEFR $(r=-0.375, P=0.071)$, eosinophilic counts $(r=-0.054, P=0.796)$ or age $(r=$ $0.181, P=0.385$ ). In addition, no statistically significant differences were found between serum ECP levels in males compared with females both in the control group $(t=$ 
Table 6 Least significant difference between asthmatic patlents subgroups versus each other and verous the oontrol group for physiological paramotors, oooinophilic counts and oosinophil cationlc proteln (ECP) levels

\begin{tabular}{lcccc}
\hline Groups & $\mathrm{O}_{2}$ saturation $\%$ & PEFA & Eosinophllic count & ECP \\
\hline Control and mild & $1.12 \mathrm{NS}$ & $17.02 \mathrm{NS}$ & $502.36 \mathrm{NS}$ & $2.11 \mathrm{NS}$ \\
Control and moderate & $1.07 \mathrm{NS}$ & $17.02 \mathrm{NS}$ & $481.84 \mathrm{NS}$ & $2.02 \mathrm{NS}$ \\
Control and severe & $1.12 \mathrm{NS}$ & $17.02 \mathrm{NS}$ & $502.36^{\mathrm{a}}$ & $2.11^{\mathrm{b}}$ \\
Mild and moderate & $1.30 \mathrm{NS}$ & $20.34 \mathrm{NS}$ & $583.38 \mathrm{NS}$ & $2.45 \mathrm{NS}$ \\
Mild and severe & $1.34 \mathrm{NS}$ & $20.34 \mathrm{NS}$ & $600.43 \mathrm{NS}$ & $2.52^{\mathrm{a}}$ \\
Moderate and severe & $1.30 \mathrm{NS}$ & $20.34 \mathrm{NS}$ & $583.38 \mathrm{NS}$ & $2.45^{\mathrm{a}}$ \\
\hline
\end{tabular}

$P<0.05 \quad$ oP $<0.01$

$P E F R=$ peak expiratory flow rate $\quad$ NS $=$ not significant

Table 7 Physiological parameters, eosinophilic counts and eosinophil cationic protein (ECP) levels in asthmatic subgroups during and 2 weoks after the attacks

\begin{tabular}{|c|c|c|c|c|c|c|c|c|}
\hline \multirow[t]{2}{*}{ Varlable } & \multicolumn{3}{|c|}{ Patients during attacks } & \multicolumn{3}{|c|}{ Potlents after attaciks } & \multirow{2}{*}{$\begin{array}{l}\text { Paired } \\
\text { ftest }\end{array}$} & \multirow[t]{2}{*}{ Pvalue } \\
\hline & Mild & Moderate & Severe & Mild & Moderate & Smare & & \\
\hline \multicolumn{9}{|c|}{$\mathrm{O}_{2}$ saturation (\%) } \\
\hline Mean & 95.75 & 92.33 & 87.75 & 98.75 & 99.22 & 98.25 & $\begin{array}{l}t_{1}=6.48 \\
t_{2}=11.27\end{array}$ & $\begin{array}{l}0.0001^{\prime \prime} \\
0.0001^{\mathrm{s}}\end{array}$ \\
\hline$s$ & 0.88 & 1.80 & 1.58 & 0.70 & 0.83 & 1.48 & $t_{3}=13.48$ & $0.0001^{12}$ \\
\hline \multicolumn{9}{|c|}{$\begin{array}{l}\text { PEFR (as \% } \\
\text { of prodicted) }\end{array}$} \\
\hline Mean & 80.38 & 60.67 & 44.13 & 95.71 & 94.20 & 86.71 & $\begin{array}{l}t_{1}=4.33 \\
t_{2}=6.88\end{array}$ & $\begin{array}{c}0.003^{a} \\
0.0001^{\mathrm{a}}\end{array}$ \\
\hline s & 5.823 & 5.009 & 3.007 & 6.91 & 10.01 & 6.66 & $t_{3}-4.86$ & $0.002^{2}$ \\
\hline \multicolumn{9}{|c|}{$\begin{array}{l}\text { Eosinophilic count } \\
\quad(\mathrm{cells} / \mathrm{cm})\end{array}$} \\
\hline Mean & 487.50 & 493.88 & 943.75 & 393.75 & 666.66 & 762.50 & $\begin{array}{l}t_{1}=0.62 \\
t_{2}=0.20\end{array}$ & $\begin{array}{l}0.554 \text { NS } \\
0.843 \text { NS }\end{array}$ \\
\hline$s$ & 355.31 & 625.82 & 604.41 & 326.71 & 671.75 & 560.45 & $t_{3}=0.89$ & 0.404 NS \\
\hline \multicolumn{9}{|c|}{$E C P(\mu g /)$} \\
\hline Mean & 9.77 & 10.0375 & 18.57 & 4.53 & 4.55 & 7.65 & $\begin{array}{l}t_{2}=2.26 \\
t_{1}=2.7\end{array}$ & $\begin{array}{l}0.048^{b} \\
0.038^{b}\end{array}$ \\
\hline$s$ & 7.243 & 6.143 & 10.66 & 1.17 & 1.79 & 2.88 & $t_{3}=3.73$ & 0.0070 \\
\hline
\end{tabular}

*P $<0.01 \quad$ oP $<0.05$

$\mathrm{t}_{1}=$ paired $\mathrm{t}$-test comparing asthmatic patients belore and after mild attacks

$\mathrm{t}_{2}=$ paired $\mathrm{t}$-test comparing asthmatic patients before and after moderate attacks

$\mathrm{t}_{3}=$ paired $\mathrm{t}$-test comparing asthmatic patients before and after severe attacks

PEFR = peak expiratory flow rate NS $=$ not significant $\mathbf{s}=$ standard deviation 
$0.6, P=0.55)$ and the asthmatic group $(t=$ $0.17, P=0.86$ ).

\section{Discussion}

Serum ECP seems to be dependent on the concentrations of eosinophils in the blood and, more significantly, on the ability of the cells to degranulate and secrete their proteins during coagulation. The coagulation process can be regarded as an inflammatory cascade reaction that triggers the eosinophils. More activated eosinophils cause higher amounts of ECP to be secreted resulting in higher ECP levels [7]. A high serum ECP level indicates that a large proportion of the eosinophils circulating have been primed. i.e. exposed to various systemic priming agents as a result of an ongoing inflammation [14].

Our results showed that the serum ECP level was significantly elevated for all the asthmatic children, both during and 2 weeks after acute attacks. Moreover, the serum ECP level for all the asthmatic children during acute exacerbation was significantly higher than when they were asymptomatic again, 2 weeks after the acute attack. These findings concur with previous studies that have shown higher ECP levels in the serum of asthmatic children when compared with healthy subjects and higher levels in symptomatic asthmatic children than in asymptomatic children $[8,10,11,15]$.

Contrary to these studies and to our results, Ferguson et al. found that the serum ECP level in asthmatic children with symptoms was not significantly higher than for asymptomatic asthmatic children or children with only allergic rhinitis [9]. These differences may be due to the fact that they studied mild asthma cases - they observed no significant difference between the forced expiratory volume in 1 second (FEV1) of children with symptomatic asthma and those with asymptomatic asthma. Also 14 out of their 24 patients with symptomatic asthma were receiving inhaled corticosteroids which might have reduced their ECP level.

Our results also suggest that serum ECP levels differ between control children and those with all grades of asthma (whether mild, moderate or severe) and between cases with severe asthma attacks and those with mild or moderate attacks. The absence of any observed significant difference between mild and moderate attacks may be due to the small number of cases we were able to study or because the level of inflammation in mild and moderate cases does not differ significantly. Other studies support our findings that the level of serum ECP is related to the activity and the severity of the asthma attack $[5,8,11]$.

Unlike cases with mild and moderate attacks, patients with severe asthma, although they showed significant drops in serum ECP levels after their acute attacks, retained a higher mean level than normal control subjects. These findings prove that in severe asthma cases, despite evident clinical improvement, the inflammatory process is continuing. This may indicate the need to intensify and/or prolong antiinflammatory treatment during severe attacks of hronchial asthma. Other investigators have found that eosinophilic inflammation may be present in the bronchi of asthmatic children even when their symptoms are minimal or absent [9]. In addition, recent reports have provided convincing evidence that bronchial inflammation $[16,17]$ and elevated levels of eosinophil granule associated proteins [17] are even present in the bronchoalveolar lavage fluid of patients whose asthma is stable, suggesting that ongoing recruitment and acti-

المحكلة الصحية لشرق المتوسط، منظمة الصهحة العالية، المجلد الحخامس، المعلد ؛ ، 1999 
vation of inflammatory cells may also be occurring in asymptomatic asthmatic individuals. This means that determination of the level of serum ECP would not only prove the severity of ongoing inflammation but could also allow the monitoring of therapy and intervention.

In accordance with other investigations, our results showed no age or sexrelated differences in serum ECP levels $[18,19]$. We found no significant correlation between the serum ECP level and the physiological parameters used in our assessment of asthma severity, namely oxygen saturation and PEFR. Contradictory results have been reported regarding the relationship between pulmonary function tests, such as FEV1 and PEFR, and serum ECP levels. A significant inverse correlation between serum ECP levels and pulmonary function has been reported by Zimmerman et al. [10] in asthmatic children and by Griffin et al. [20] in asthmatic adults. Our results, however, agree with data from Carlson et al. [21], Niggemann et al. [22] and Hoshino and Nakamura [23] who could not find a significant correlation between serum ECP and either airway hypersensitivity or pulmonary function. The lack of a correlation is not surprising as it is possible that the kinetics of changes in lung function may differ from those of changes in inflammatory parameters.

Blood eosinophil counts have for several decades been viewed as a valuable tool for indicating disease severity; possibly because they reflect the degree and extent of inflammation in the asthmatic lung [7]. Studies have reported a correlation between the number of blood eosinophils and the severity of asthma $[20,24]$. In the clinical management of patients with bronchial asthma blood eosinophilia was considered a risk factor, indicating deterioration and exacerbation [25]. However, patients with asthma may have a normal number of eosinophils in their blood [26], bronchial biopsy specimens from patients who have died of status asthmaticus do not always reveal eosinophils [27] and histological studies performed after bronchoscopy in patients with asthma have not always found eosinophils in the bronchial mucosa [28].

In our study a comparison between the control group and all asthmatic patients showed that the mean esoinophilic count was significantly higher for asthmatic patients both during and after the acute attacks; however, no significant difference was detected between asthmatic patients during, compared with after, the attacks. Thus, the eosinophilic count cannot be used as a blood marker of disease activity in childhood bronchial asthma. Comparison of the eosinophilic counts for asthmatic attacks of differing severity revealed that only the mean eosinophilic count of patients with severe attacks was higher than that of the control group and remained higher after the attack. No significant differences were found between eosinophilic counts of the control group and asthmatic patients during and after mild and moderate attacks. Based on these results and the inconsistent findings of other investigators $[7,20,24-28]$, we cannot depend on the eosinophilic count to monitor disease activity. In addition, measuring serum ECP levels has the advantage over eosinophilic count in that it reflects not only the number of eosinophils but also their degree of activation and is therefore a better inflammatory marker $[8]$.

No significant correlation was found between ECP levels in asthmatic patients during acute exacerbation and their eosinophilic count. This concurs with other studies where no significant correlations were found between serum ECP levels and the peripheral eosinophil counts $[23,29]$. This 
may be because ECP levels are related to degranulation and the activity of eosinophils rather than the eosinophilic count. On the other hand, some studies have found a positive correlation between eosinophilic count and serum ECP levels $[18,19]$.

\section{Conclusions}

Our findings demonstrated increased serum ECP concentrations in children with bronchial asthma, especially during acute exacerbation. These results increase the likelihood that eosinophils play a central part in asthmatic inflammation in children as well as in adults. In addition, our data suggest that the measurment of serum ECP levels may be used for monitoring disease activity. High levels of serum ECP may be a predictor and a risk factor for asthma exacerbation and therefore be potentially useful for guiding treatment intensity. The value of serum ECP, along with symptoms, lung functions and bronchial hyperreactivity should be further studied with the aim of optimizing drug therapy for asthma patients. It may be that assessment of mediators will allow further investigation into important and until now unanswered questions concerning childhood asthma such as: when does eosinophilic inflammation start in the asthmatic child, and what comes first, bronchial hyperreactivity or inflammation? However, such measurements should always be judged in relation to the clinical situation.

\section{Acknowledgement}

The authors thank Dr Ola A. Sharaki, Clinical Pathology Department, University of Alexandria for her great help in the immunoenzymatic assay of serum ECP.

\section{References}

1. Frigas $\dot{E}$, Gleich $G J$. The eosinophil and the pathophysiology of asthma. Joumal of alleroy and clinical immunology, 1986, 77(4): 527-37.

2. Gleich GJ, Adolphson CR. The eosinophilic leukooyte: struature and function. Advances in immunology, 1986, 39:177-253.

3. Global strategy for asthma management and prevention. NHLBIWHO Workshop Bethesda, Maryland, National Institutes of Hoalth, National Heart, Lung and Blood Institute, 1995 (Publication number 95-3659).

4. Venge P. Serum measurement of eosinophil cationic protein (ECP) in bronchial asthma. Clinical and experimental allergy, 1993, 23 (suppl. 2):3-7.

5. Bousquet $\mathrm{J}$ et al. Eosinophilic inflammation in asthma. New England joumal of medicine, 1990, 323(15):1033-9.

6. Virchow JC, Holscher U, Virchow C. Sputum ECP levels correlate with parameters of airflow obstruction. American review of respiratory disease, 1992, 146(3):604-6.

7. Dahl R. Monitoring bronchial asthma in the blood. Allergy, 1993, 48:77-80.

8. Koller DY et al. Clinical value of monitoring oosinophil activity in asthma. Archives of disease in childhood, 1995, 73(5):413-7. 
9. Ferguson $\mathrm{AC}$ et al. Evaluation of serum eosinopnilic cationic proteln as a marker of disease activity in chronic asthma. Joumal of allergy and clinical immunology, 1995, 95:20-8.

10. Zimmerman B et al. Total blood eosinophils, serum eosinophil cationic protein and eosinophil protein $X$ in childnood asthma: relation to disease status and therapy. Clinical and experimental allengy, 1993, 23(7):564-70.

11. Sugai T, Sakiyama $Y$, Matumoto $S$. Eosinophil cationic protein in peripheral blood of pediatric patients with allergic diseaes. Clinical and experimental allergy, 1992, 22(2):275-81.

12. American Academy of Pediatrics. Provisional Committee on Quality Improvement. Practice parameter: the office management of acute exacerbations of asthma in children. Pediatrics, 1994, 93(1):119-22.

13. Peterson CG et al. Radioimmunoassay of human eosinophil cationic protein (ECP) by an improved method. Establishment of normal levels in serum and turnover in vivo. Clinical and experimental allergy, 1991, 21(5):561-7.

14. Ahlstedt $S$ et al. The clinical assessment of the inflammatory component in asthma with emphasis on the eosinophils. Practical allergy and immunology, 1993, 8(4):149-54.

15. Robinson DS et al. Eosinophil cationic protein (ECP) and eosinophil protein $X$ (EPX) concentrations in serum and bronchial lavage fluid in asthma. Effect of prednisolone treatment. Clinical expenmental allergy, 1995, 25(11):1118-27.

16. Oddera $S$ et al. Airway eosinophilic inflammation, epithelial damage and bronchial hyperresponsiveness in patients with mild-moderate stable asthma. Allergy, 1996, 51(2):100-7.
17. Bousquet et al. Indirect evidence of bronchlal Inflammation assessed by titration inflammatory mediators in BAL fluid of patients with asthma. Joumal of allorgy and olinioal immunology, 1901, 88(4):649-60.

18. Tomassini $M$ et al. Serum levels of eosinophil cationic protein in allergic diseases and natural allergen exposure. Joumal of allergy and clinical immunology, 1996, 97(6):1350-5.

19. Bjornsson E et al. Serum eosinophil cationic protein in relation to bronchial asthma in a young Swedish population. Allergy, 1994, 49(9):730-63.

20. Griffin E et al. Blood eosinophil number and activity in relation to lung function in patients with asthma and with eosinophilia. Joumal of allergy and clinical immunology, 1991, 87(2):548-57.

21. Carison $\mathbf{M}$ et al. Degranulation of eosinophils from pollen-atopic patients with asthma is increased during pollen season. Joumal of allergy and clinical immunology, 1992, 89:131-9.

22. Niggemann B et al. Twenty-four-hour time course of eosinophil granule proteins ECP and EPX during bronchial allergen challenges in serum of asthmatic children. Allergy, 1994, 49(2):74-80.

23. Hoshino $M$, Nakamura $Y$. Relationship between activated eosinophils of the bronchial mucosa and serum eosinophil cationic protein in atopic asthma. International archives of allergy and immunology, 1997, 112(1):59-64.

24. Burrowe B et al. Epidemiologic observations on eosinophilia and its relation to respiratory disorders. American review of respiratory disease, 1980 . 122(5):709-19.

25. Janson C, Herala M. Blood eosinophil count as risk factor for relapee in acute 
asthma. Respiratory medicine, 1992, $86(2): 101-4$.

26. Bruijnzeel PL et al. Blood lymphocyte eubpopulations in oxtrinsic and intrinsic asthmatics. Annals of allergy, 1987, 58(3): $179-82$.

27. Gleich GJ et al. The eosinophilic leukocyte and the pathology of fatal bronchial asthma: evidence for pathologic heterogeneity. Joumal of allergy and clinical immunology, 1987, 80:412-5.
28. Lundgren R et al. Morphological studies of bronchial mucosal biopsies from asthmatics before and after ten years of treatment with inhaled steroids. European respiratory joumal, 1988, 1(10):883-9.

29. Kristjansson $S$ et al. Urinary eosinophil protein $X$ in children with atopic asthma: a useful marker of anti-inflammatory treatment. Joumal of allergy and clinical immunology, 1996, 97(6):1179-87.

WHO recognizes asthma as a disease of major public health importance and plays a unique role in the coordination of internatlonal efforts against the disease. International action is needed to:

- Increase public awareness of the disease to make sure patients and health professionals recognize the disease and are aware of the severity of assoclated problems;

- organize and coordinate global epidemiological survelliance to monitor global and regional trends in asthma;

- develop and implement an optimal strategy for its management and prevention (many studies have shown that this will result in the control of asthma in most patlents); and

- stimulate research Into the causes of asthma to develop new control strategles and treatment techniques.

The first steps have already been taken. WHO collaborates in the International Study of Asthma and Allergles in Childhood (ISAAC) and, more particularly, in the implementation of the study in developing countries with areas of severe alr pollution. A preliminary obJective is to obtain information on the assoclation between childhood asthma and air pollution. The first results of this study have shown the prevalence of asthma symptoms to vary from $1.6 \%$ to $36.8 \%$

Source: WHO Fact sheet No. 206, December 1998

المُملة الصحية لشرت المثوسط، منظيمة الصحة العالمية، المحجلد المخامس، العلد ع ، 1999 